\title{
THE LEGAL FRAMEWORK OF OCCUPATIONAL SAFETY AND HEALTH SYSTEM IN SERBIA AND MONTENEGRO: COMPARATIVE REVIEW
}

UDC 331.45(497.11+497.16)

\author{
Aleksandra Ilić Petković ${ }^{1}$, Jovan Simić², Ivan Krstić \\ ${ }^{1}$ Faculty of Occupational Safety, University of Niš, Serbia \\ 2“Telekomunikacija”, Limited liability company for manufacturing, services and trade, \\ Blace, Serbia
}

\begin{abstract}
One of the most important interests of each society is to establish the highest level of occupational safety and health, with the aim of minimizing all adverse effects: injuries at work, occupational diseases, work-related illnesses. The ultimate imperative is the creation of such workplace conditions where the employee would have a sense of satisfaction in performing the assigned professional tasks. One way to achieve this ambitious goal is to have a legal regulation that creates a platform for effective occupational safety. This paper analyzes the legislation on occupational safety and health in the Republic of Serbia and the Republic of Montenegro. By comparing these two legal systems in the field of occupational safety and health, we will discuss the advantages and deficiencies of each, and provide some ideas for their improvement.
\end{abstract}

Key words: occupational safety and health, regulations, Serbia, Montenegro.

\section{INTRODUCTION}

Occupational safety and health imply the fulfillment of such conditions of work in which certain measures and activities are undertaken in order to protect the life and health of employees and other persons who are entitled to that right. This concept has been analyzed by numerous theorists and it is the subject matter of study in many scientific disciplines: sociology, law, economics, psychology, etc. (Anđelković, 2010:154-155). The goal of the society as a whole, and each individual in particular, is to create the highest possible level of safety and health at work. Every company should make an effort to minimize injuries at work, occupational diseases and work-related illnesses, which

Received October $2^{\text {nd }}, 2018 /$ Accepted October $31^{\text {st }}, 2018$

Corresponding author: Aleksandra Ilić Petković, Assistant Professor, Faculty of Occupational Safety, University of Niš, Čarnojevića 10a, 18000 Niš, Republic of Serbia

E-mail: aleksandra.ilic@ znrfak.ni.ac.rs 
implies the creation of a work environment in which an employee would have the sense of satisfaction in performing the assigned professional tasks. It is not easy to achieve such ambitious goals but the legal regulation of this matter may significantly contribute to accomplishing these goals.

Occupational safety and health are regulated by numerous legal acts: the constitution, laws, by-laws. When looking at the hierarchy of legal documents of a state, the constitution has the highest legal power; it is followed by legislative acts and, finally, bylaws (administrative acts, rulebooks, decisions, etc.). Strategic documents are also of great importance for the regulation of this issue. All these types of legal documents regulate the issue of safety and health at work in any country, including the Republic of Serbia and the Republic of Montenegro.

This paper will provide comparative analysis of legal regulations on occupational safety and health in the Republic of Serbia and the Republic of Montenegro. Since Serbia and Montenegro were until recently constituent parts of one state, it is important to examine the directions in the development of respective legal frameworks of their occupational safety and health systems. Firstly, the issue of occupational safety and health will be analyzed by examining the constitutional documents of the respective states, and then the strategic documents, legislative acts and by-laws. In the Republic of Serbia, occupational safety and health issues are regulated in the Serbian Constitution, the Strategy on Health and Safety at Work, Occupational Safety and Health Law, and many by-laws, primarily administrative acts and rulebooks (Ilić-Petković, 2017:119-122). Within the legal system of Montenegro, we analyzed the Constitution, the Strategy for the Promotion of Occupational Safety and Health, the Act on Safety and Health at Work, and by-laws (primarily rulebooks).

Based on the provided review of the aforesaid regulations applicable in both countries, we will compare the types of documents that address the issue of workplace safety and health. It will allow us to observe the extent to which legal regulations on safety and health at work in these countries have been developed, compare the degree of development of their legal systems in this area, and consider the possibility of adopting some new regulations on this matter in Serbia. All this will undoubtedly contribute to the improvement of occupational safety and health legislation in both countries.

\section{CONSTITUTIONAL DOCUMENTS}

The right to safety and health at work is guaranteed by the Constitution of the Republic of Serbia ${ }^{1}$, which envisages that everyone has the right to occupational safety and respect for the dignity of each person at work. As the highest legal act and the basic source of rights, the Serbian Constitution guarantees the right to work, the right to respect of dignity at work, safe and healthy working conditions, necessary workplace protection, limited working hours, daily and weekly rest, paid annual holiday, fair remuneration for work done, and the right to legal protection in case of termination of employment. No person can forgo these rights. Women, young and people with disabilities are provided with special protection at work and special working conditions, in accordance with the law (Article 60, Constitution RS). Therefore, the Constitution of Serbia explicitly

\footnotetext{
${ }^{1}$ Constitution of the Republic of Serbia, Official Gazette RS, 98/2006
} 
guarantees the right to occupational safety in the broadest sense of the word (Krstić, Anđelković, 2013:52-53). It shows the state's awareness of the importance of this issue, which is regulated in the highest legal act.

Furthermore, the Constitution provides that the Republic of Serbia shall be competent to regulate and provide "a system in the area of labor relations, protection at work, employment, social insurance and other forms of social security" (Article 97(8), Constitution RS). This constitutional provision means that the state is obliged to adopt legal regulations and establish the necessary mechanisms in order to provide systemic functioning of occupational safety. Therefore, in the Republic of Serbia, the right to protection at work is classified as one of the most important rights guaranteed by the Constitution as the legal act of highest legal force. Further elaboration of these constitutional principles is achieved through legal regulations in the field of occupational safety and health and the documents of lower legal force. Thus, the Occupational Safety and Health $\mathrm{Act}^{2}$ is a basic legislative act which elaborates on the aforesaid constitutional proclamations and provides for their application in practice. Numerous by-laws have been adopted on the basis of this Act. Strategic documents that rely on the Constitution and the enacted normative framework are of special importance in this area of law.

The Constitution of the Republic of Montenegro was adopted in $2007^{3}$. The Constitution guarantees the right to work, free choice of occupation and employment, fair and humane working conditions and protection during unemployment. Every employee has the right to adequate earnings, as well as the right to limited working hours and paid annual holiday. The Constitution explicitly states that all employees have the right to protection at work, while the right to special protection at work is provided for the young, women and people with disabilities (Article 64, Constititution RM). In Montenegro, the constitutional proclamations are further elaborated in the Act on Safety and Health at Work, a number of regulations, and particularly the Strategy for the Promotion of Occupational Safety and Health.

Therefore, in the Constitution of Montenegro, the right to protection at work is regulated in a similar way as in the Constitution of Serbia. In both cases, the right to protection at work is considered as a special right that is unambiguously and explicitly treated as one of the highest-ranked rights in the state. It indicates that both countries are aware of the fact that motivated and satisfied workers are an important prerequisite for the social and economic well-being of each state. Occupational safety and health contribute to greater employee satisfaction, greater productivity and greater interest in achieving organizational goals and interests. Ultimately, it has multiple positive effects on the state itself.

\section{STRATEGIC DOCUMENTS}

In Serbia and Montenegro, there are strategic documents dealing with the issue of occupational safety and health. In Serbia, this important document is the Strategy on Health and Safety at Work for the period 2013-2017, which is accompanied by the Action Plan for the Implementation of the Strategy for Health and Safety at Work of the

\footnotetext{
${ }^{2}$ Occupational Safety and Health Law, Official Gazette RS, 101/2005, 91/2015, 113/2017

${ }^{3}$ Constitution of the Republic of Montenegro, Official Journal of the Republic of Montenegro, 1/2007, 38/2013
} 
Republic of Serbia for the period 2013-2017. In Montenegro, the Strategy for the Promotion of Health and Safety at Work for 2016-2020 is currently in force, alongside with the Action Plan for its implementation.

The Strategy on Health and Safety at Work in the Republic of Serbia for the period 2013-2017 is a governmental act which fully determines the circumstances in the field of safety and health at work in Serbia, and stipulates the measures to be taken for its development. In other words, it defines the activities, goals and directions of improvement in this area. This strategy is a continuation of the implementation of the previous strategy that was valid for the period from 2009 to 2012. As in the previous period, this Strategy aims to create a socio-economic motivation for all participants in the work processes in order to increase the number of business entities who actively manage occupational safety and health, and improve the conditions in this area. Based on this Strategy, which was envisaged for the period until 2017, a new one is to be adopted for the upcoming period.The development of a new strategic document is in progress and it is expected to set new goals in this area, based on the overview of the current situation and the analysis of effects that were achieved on the basis of the Strategy for the 2013-2017 period.

The vision of the Strategy for the period 2013-2017 is continuous work on improving this area by supporting the regulations in the field of occupational safety and health, joint work of employers and employees in the improvement of this area, raising awareness in this area, improving knowledge and skills, establishing work ethics and creating preconditions for work-related well-being and the quality of life and health at work. The mission of the Strategy is to establish a system that delivers safe and healthy working conditions and ensures the reduction of occupational injuries, occupational diseases and work-related illnesses. Of course, it can be expected that the next strategic document shall have its own vision and mission based on such ideals. Similar to the currently valid document, the next strategic document is expected to provide for establishing the institutional framework for its realization, an overview and description of the current situation, identification of the general and individual strategy goals, proposal of activities and measures for the realization of the goals set, etc. Based on this Strategy, the Action Plan for the Implementation of the Strategy on the Safety and Health at Work of the Republic of Serbia for the period $2013-2017^{5}$ was adopted as an accompanying document, which is also expected in terms of the new strategy for the forthcoming period.

In Montenegro, the main strategic document related to occupational safety and health of employees is the Strategy for the Promotion of Occupational Health and Safety in Montenegro 2016-2020, with the Action Plan for its Implementation ${ }^{6}$. The Strategy points out that Montenegro, through the ongoing transition process, has a humane development strategy with the desire to keep up with the trends of the advanced social achievements among the European peoples within the framework of the established integration. To this end, it is important to establish new and contemporary development goals within the framework of occupational safety and health of the employees in their working and social environment, based on the previous experience and achievements of

\footnotetext{
${ }^{4}$ Strategy on Health and Safety at Work in the Republic of Serbia for the period from 2013 to 2017, Official Gazette RS, 100/2013

${ }^{5}$ Conclusion on the Adoption of Action Plan for the Implementation of Strategy on Health and Safety at Work in the Republic of Serbia for the period from 2013 to 2017, Official Gazette RS, 81/2014

${ }^{6}$ Strategy for the Promotion of Occupational Health and Safety in Montenegro 2016-2020, with the Action Plan for its Implementation, http://www.uznr.me/regulative/Strategija\%20ZZNR.pdf, 22.12.2017.
} 
comparative legislation. The effectiveness of occupational health and safety greatly depends on the socio-economic conditions, the degree of economic development and the tradition of each state. To ensure the observance of occupational health and safety standards, it is of primary importance to have a legislative framework that defines the subjects, their rights and obligations, mutual relations, responsibilities, activities and instruments for exercising these rights.

The vision of occupational health and safety is reflected in the need to ensure the development of prevention and improvement of occupational health and safety through safe and healthy workplaces that will create adequate working conditions for employees and employers alike, productivity growth, competitiveness and economic development. The mission is to set and apply quality standards in occupational safety, strengthen the quality of work of occupational safety professionals, raise awareness, provide data monitoring and system analysis, exchange good practice, improve the information flow and knowledge in the field of occupational health and safety ${ }^{7}$. This Strategy includes a legal framework for occupational health and safety. It also provides a vision of occupational health and safety, provides an overview and analysis of the current situation, assesses the main challenges, sets out key strategic goals, and provides the Action Plan for its implementation.

Looking at the strategic documents enacted in the two countries, it can be noted that Serbia has a strategy and an action plan as two separate documents, while Montenegro has a strategy with the action plan as a single document. In terms of validity, it can be noticed that the Strategy of Montenegro is a currently valid document whereas the Strategy of Serbia expired in 2017, so it is necessary to ensuring legal continuity by adopting a new one in the near future. In general, the structure of both strategies is similar and the strategic goals of both countries are similar in nature, given the similar circumstances and challenges in both countries.

\section{LEGISLATIVE ACTS}

Both the Republic of Serbia and the Republic of Montenegro have enacted legislative acts which regulate the occupational safety and health system. In Serbia, this matter is regulated by the Occupational Safety and Health Act, adopted in 2005; in Montenegro, it is regulated by the Act on Safety and Health at Work, adopted in 2014.

In Serbia, the Occupational Safety and Health Act (hereinafter: OSH Act) ${ }^{8}$ regulates the implementation and improvement of occupational safety and health of persons involved in working processes and different working environments, in order to prevent injuries at work, occupational diseases and work-related illnesses. The OSH Act was adopted in 2005 and subsequently amended in 2015 and 2017 in order to eliminate certain shortcomings observed in its former implementation. This Act defines the persons entitled to occupational safety and health protection, determines preventive measures for ensuring workplace safety and health, stipulates the obligations and responsibilities of the employer in relation to ensuring safety and health at work (general obligations, special obligations and training for employees). It also regulates the rights and obligations of employees, the way of organizing the task of occupational safety and health, the possibility of selecting representatives among

\footnotetext{
${ }^{7}$ Strategy for the Promotion of Occupational Health and Safety in Montenegro 2016-2020, with the Action Plan for its Implementation, http://www.uznr.me/images/2018/regulativa/Strategija_ZZNR.pdf 22.12.2017. (p.5); ${ }^{8}$ Occupational Safety and Health Act, Official Gazette RS, 101/2005, 91/2015, 113/2017
} 
the employees for occupational safety and health, obligations of the employer related to keeping records, information exchange and cooperation with relevant institutions, the issue of the professional exam and licensing, the competence of the Occupational Safety and Health Administration. The provisions of the Occupational Safety and Health Act are further elaborated in numerous by-laws, for the purpose of regulating the specific implementation procedures.

In Montenegro, the Act on Safety and Health at Work was adopted in 2014. ${ }^{9}$ It stipulates that health and safety at work are ensured and implemented through the application of modern technical, technological, organizational, health, social and other measures and means of protection (Art 1). According to this Act, occupational health and safety imply providing working conditions that do not lead to injuries at work, occupational diseases and work-related illnesses, and create preconditions for full physical and psychological protection of employees (Art 2). In addition to its basic provisions, the Act contains general conditions and protection measures, regulates the rights, obligations and responsibilities of the employer (to secure and implement the protection measures, risk assessment, etc.), as well as the rights and obligations of employees, organization of occupational health and safety at work, the obligations in terms of keeping records, cooperation and reporting, and the like. The provisions of this Act are further elaboated in numerous by-laws.

Based on the analysis of the structure of the Montenegrin Act on Safety and Health at Work, it can be noted that its structure is very similar to the structure of the Serbian Occupational Safety and Health Act. Furthermore, the majority of legal solutions are similar or identical in nature, which is a logical consequence of common social, political, economic and cultural circumstances in these two countries.

\section{BY-LAWS}

In Serbia and Montenegro, there is a number of by-laws that regulate and elaborate more closely the provisions of the aforementioned legislative acts. When it comes to the structure of by-laws, there are several acts and rulebooks in the field of occupational safety and health which are in force in Serbia. In Montenegro, this issue is regulated only by rulebooks.

In Serbia, safety and health at work are regulated by 8 administrative acts and 55 rulebooks (Ministry of Labor, Employment, Veterans' Affairs and Social Affairs of the Republic of Serbia, 2017). In Montenegro, this issue is regulated by 46 rulebooks (Ministry of Labor and Social Welfare of the Republic of Montenegro, 2017). The number of these by-laws should be taken only provisionally, given that new regulations are being adopted all the time. Namely, some issues regulated in these by-laws are directly related to protection of employees at work, primarily their physical integrity. There are many regulations of this kind, such as: the Rulebook on Preventive Measures for Safe and Healthy Work when Exposed to Biological Hazards in the Republic of Serbia (2010) ${ }^{10}$, or the Rulebook on Measures of Protection when using Work Equipment in Montenegro

\footnotetext{
${ }^{9}$ Law on Safety and Health at Work, Official Journal of the Republic of Montenegro, 34/2014

${ }^{10}$ Rulebook on Preventive Measures for Safe and Healthy Work when Exposed to Biological Hazards, Official Gazette RS, 96/2010
} 
$(2015)^{11}$. In fact, the largest number of rulebooks in both countries deals with the protection of the physical integrity of the employees. But, taking into account the need to protect their psychological and moral integrity at work, the number of these regulations has significantly increased. An example of such regulation in Serbia is the Rulebook on the Rules of Conduct of Employers and Employees concerning Prevention and Protection from Harassment at the Workplace (2010). ${ }^{12}$

In examining the by-laws enacted in the two countries, we may conclude that they can be classified into several groups. The first group consists of by-laws existing in both countries in the form of rulebooks, such as: the Rulebook on Records in Safety and Health at Work in Serbia (2015) ${ }^{13}$ and the Rulebook on Keeping Records in the Area of Safety at Work in Montenegro (2005) ${ }^{14}$. The second group includes by-laws on certain issues that are regulated in only one of these two countries. Thus, in Serbia, protection against exposure to electromagnetic fields is regulated by the Rulebook on Preventive Measures for Safe and Healthy Work When Exposed to Electromagnetic Field (2015), ${ }^{15}$ while there is no such regulation in Montenegro. On the other hand, in Montenegro, there is the Rulebook on Occupational Safety Issues which are to be Regulated by the Labor Contract (2005), ${ }^{16}$ while in Serbia this issue is not regulated by any special by-law. Finally, the third group of includes by-laws that have been in force since the time when the two countries were constituent parts of a single state. These are, for example, the Rulebook on Special Occupational Safety Measures and Rules for the Processing of Leather, Fur and Leather Refuse $(1970)^{17}$ or the Rulebook on Special Protective Measures for Thermal Processing of Light Metals Alloys in Nitrate Salts Baths (1956) ${ }^{18}$.

Therefore, it can be noted that the specific issues pertaining to safety and health at work are are regulated by administrative acts and rulebooks in Serbia, and only by rulebooks in Montenegro. It is important to bear in mind that this is only an indicative number of regulations in these countries as there are many other by-laws that deal with this issue in a certain indirect way. In fact, many labor law institutes can be examined in the context of workplace safety. Yet, it can be clearly recognized and directly realized only in some cases, while in most cases it is achieved in an indirect and less visible (but still apparent) way.

All of the aforementioned documents clearly play a significant role in ensuring adequate working conditions and occupational health and safety protection by specifying the procedural rules regulating the application of the provisions envisaged in the legislative acts of the two countries.

\footnotetext{
${ }^{11}$ Rulebook on Measures of Protection when Using Work Equipment, Official Journal of the Republic of Montenegro, 27/2015

${ }^{12}$ Rulebook on the Rules of Conduct of Employers and Employees Concerning Prevention and Protection from Harassment at the Workplace, Official Gazette RS, 62/2010

${ }^{13}$ Rulebook on Records in Safety and Health at Work, Official Gazette RS, 62/2007, 102/2015

${ }^{14}$ Rulebook on Keeping Records in the Area of Safety at Work, Official Journal of the Republic of Montenegro, $67 / 2005$

${ }^{15}$ Rulebook on Preventive Measures for Safe and Healthy Work When Exposed to Electromagnetic Field, Official Gazette RS, 111/2015

${ }^{16}$ Rulebook on Occupational Safety Issues which Are to Be Regulated by the Labor Contract, Official Journal of the Republic of Montenegro, 67/2005

${ }^{17}$ Rulebook on Special Occupational Safety Measures and Rules for the Processing of Leather, Fur and Leather Refuse, Official Journal SFRJ, 47/1970

${ }^{18}$ Rulebook on Special Protective Measures for Thermal Processing of Light Metals Alloys in Nitrate Salts Baths, Official Journal SFRJ, 48/1965
} 


\section{INSTEAD OF A CONCLUSION: THE IMPORTANCE OF UNIFYING REGULATIONS ON OCCUPATIONAL SAFETY AND HEALTH}

Occupational safety and health imply ensuring the working conditions in which activities and measures can be taken to protect the life and health of employees and other persons who are entitled to exercise these right. The interest of each individual, society and all other subjects is to achieve the highest possible level of workplace safety and health, and to minimize all adverse effects (injuries at work, occupational diseases and work-related illnesses). The goal of every society is to provide working conditions which would generate the sense of satisfaction in employees performing the assigned professional tasks. This goal is a serious challenge for every society. Legal regulations of the state play an important part in accomplising this goal because they provide a normative framework for the occupational health and safety system, which provides the rules of conduct for all entities within the system and sanctions for their violation.

In that sense, the unification of regulations on occupational safety and health at the level of several states, or states within a region or, ideally, the entire international community, would be a step forward. What is realistic in the current circumstances is the unification or, at least, harmonization of workplace safety and health regulations of neighboring states which have similal social, political, economic and other circumstances, which is the case with the Republic of Serbia and the Republic of Montenegro. Until recently, they were an integral part of one state, and they are both in the process of transitiontran, which makes them similar in many respects..

Based on the conducted research and provided comparative analysis of occupational safety and health regulations in the two countries, a number of conclusions can be drawn. First, occupational safety and health is a right guaranteed by the constitutional documents of both countries. In this way, both countries clearly demonstrate their determination to regulate the occupational health and safety system as a matter of highest importance. Then, in both countries, there is a legislative act that regulates workplace health and safety: the 2005 Occupational Safety and Health Act in the Republic of Serbia, and, the 2014 Act on Safety and Health at Work in Montenegro. The fact that the Serbian act was passed considerably earlier than the Montenegrin one may imply that Serbian experience in the application of this law could have served as a basis for the same act in Montenegro. The process of drafting a new law on safety and health at work is under way in Serbia, which means that the Montenegrin experience can be useful in regulating this issue in Serbia. Furthermore, there is a number of by-laws pertaining to this matter in both countries. In Serbia, the Occupational Safety and Health Act is elaborated in administrative acts and rulebooks, while in Montenegro there are rulebooks only. Serbia has adopted more by-laws than Montenegro, which may be a logical consequence of the fact that its current law has been applied since 2005. It can also be concluded that both countries have rulebooks with similar or identical names, indicating that both of them have recognized the need to regulate these issues in more detail. Then, there are the issues that are regulated by rulebooks in one state but remain unregulated in the other. Finally, the normative frameworks of both states include some rules which have been applied since the 1960s or 1970s, when Serbia and Montenegro were constituent parts of a single state. In addition to all the aforementioned regulations, both countries have their own strategies in this area, accompanied by relevant action plans, all of which confirms their commitment to establishing an effective occupational health and safety system. 
Based on all of the above, it is a positive fact that both countries contain a normative framework pertaining to the system of occupational safety and health. The framework includes: a) constitutional documents: the Constitution of R. Serbia and the Constitution of R. Montenegro; b) legislative acts: the Occupational Safety and Health Act in Serbia and the Act on Safety and Health at Work in Montenegro; c) by-laws (primarily rulebooks); and d) strategic documents on occupational safety and health. However, in every legal system, regulations have full meaning only if they are applied in practice. It is the ultimate test for assessing the actual operation and effectiveness of any system, including the occupational safety and health system. Therefore, it is important to bear in mind that these two states should provide efficient mechanisms for controlling the application of all of the aforementioned regulations and effective sanctions for their violation. Only then will the envisaged regulations be fully meaningful and puposeful. Controlling the application of the envisaged regulations should be effective since it is the ultimate confirmation of the existence and regularity of a legal system.

\section{REFERENCES}

Anđelković, B., (2010). Osnovi sistema zaštite (Fundamentals of Occupational Safety), Fakultet zaštite na radu, Niš Ilić Petković, A., (2017). Državni službenici u Srbiji sa osvrtom na sistem bezbednosti i zdravlja na radu (Civil servants in Serbia with reference to the occupational safety and health system), Fakultet zaštite na radu, Niš Krstić, I., Anđelković, B., (2013). Profesionalni rizik (Professional Risk), Fakultet zaštite na radu, Niš

Zaključak o usvajanju akcionog plana za sprovođenje Strategije bezbednosti i zdravlja na radu u Republici Srbiji za period od 2013. do 2017. (Conclusion on the Adoption of Action Plan for the Implementation of Strategy on Health and Safety at Work in the Republic of Serbia for the period from 2013 to 2017), Službeni glasnik RS, 81/2014

Ustav Crne Gore (Constitution of the Republic of Montenegro), Službeni list Crne Gore, 1/2007, 38/2013

Ustav Republike Srbije (Constitution of the Republic of Serbia), Službeni glasnik RS, 98/2006

Zakon o zaštiti i zdravlju na radu (Act on Safety and Health at Work), Službeni list Crne Gore, 34/2014

Zakon o bezbednosti i zdravlju na radu (Occupational Safety and Health Act), Službeni glasnik RS, 101/2005, 91/2015, 113/2017

Ministarstvo rada i socijalnog staranja Crne Gore (Ministry of Labor and Social Welfare of the Republic of Montenegro), http://www.minradiss.gov.me/biblioteka/pravilnici, retrieved on 27.12.2017.

Ministarstvo za rad, zapošljavanje, boračka i socijalna pitanja Republik Srbije (Ministry of Labor, Employment, Veterans' Affairs and Social Affairs of the Republic of Serbia), http://www.minrzs.gov.rs/uprava-zabezbednost-i-zdravlje-na-radu.html, retrieved on 27.12.2017.

Pravilnik o vođenju evidencija iz oblasti zaštite na radu (Rulebook on Keeping Records in the Area of Safety at Work), Službeni list Crne Gore, 67/2005

Pravilnik o mjerama zaštite prilikom upotrebe sredstava za rad (Rulebook on Measures of Protection When Using Work Equipment), Službeni list Crne Gore, 27/2015

Pravilnik o pitanjima iz zaštite na radu koja treba urediti ugovorom o radu (Rulebook on Occupational Safety Issues which are to be regulated by the Labor Contract), Službeni list Crne Gore, 67/2005

Pravilnik o preventivnim merama za bezbedan i zdrav rad pri izlaganju biološkim štetnostima (Rulebook on Preventive Measures for Safe and Healthy Work when exposed to Biological Hazards), Službeni glasnik $R S, 96 / 2010$

Pravilnik o preventivnim merama za bezbedan i zdrav rad pri izlaganju elektromagnetskom polju (Rulebook on Preventive Measures for Safe and Healthy Work when exposed to Electromagnetic Field), Službeni glasnik RS, 111/2015

Pravilnik o evidencijama u oblasti bezbednosti i zdravlja na radu (Rulebook on Records in Safety and Health at Work), Službeni glasnik RS, 62/2007, 102/2015

Pravilnik o posebnim merama i normativima zaštite na radu pri preradi i obradi kože, krzna i otpadaka kože (Rulebook on Special Occupational Safety Measures and Rules for the Processing of Leather, Fur and Leather Refuse), Službeni list SFRJ, 47/1970 
Pravilnik o posebnim mjerama zaštite na radu pri termalnom obrađivanju legura lakih metala u kupatilima sa nitritnim solima (Rulebook on Special Protective Measures for Thermal Processing of Light Metals Alloys in Nitrate Salts Baths), Službeni list SFRJ, 48/1965

Pravilnik o pravilima ponašanja poslodavaca i zaposlenih u vezi sa prevencijom i zaštitom od zlostavljanja na radu (Rulebook on the Rules of Conduct of Employers and Employees Concerning Prevention and Protection from Harassment at the Workplace), Službeni glasnik RS, 62/2010

Strategija za unapređenje zaštite i zdravlja na radu u Crnoj Gori 2016-2020, sa Akcionim planom implementacije (Strategy for the Promotion of Occupational Health and Safety in Montenegro 2016-2020, with the Action Plan for its Implementation), http://www.uznr.me/regulative/Strategija\%20ZZNR.pdf, retrieved on 22.12.2017.

Strategija bezbednosti i zdravlja na radu u Republici Srbiji za period od 2013. do 2017. (Strategy on Health and Safety at Work in the Republic of Serbia for the period from 2013 to 2017), Službeni glasnik RS, 100/2013.

\section{PRAVNI OKVIR SISTEMA BEZBEDNOSTI I ZDRAVLJU NA RADU U SRBIJI I CRNOJ GORI - KOMPARATIVNI PREGLED}

Jedan od značajnijih interesa svakog društva jeste stvaranje najvišeg mogućeg nivoa bezbednosti $i$ zdravlja zaposlenih na radu, a sa ciljem da se sve neželjene posledice (povrede na radu, profesionalne bolesti, bolesti u vezi sa radom) svedu na najmanju moguću meru. Krajnji imperativ jeste stvaranje takvih uslova rada u kojima bi zaposleni imao osećaj zadovoljstva prilikom izvršavanja profesionalnih zadataka koji su pred njega postavljeni. Jedan od načina za ostvarenje ovako ambiciozno postavljenog cilja jeste postojanje pravne regulative koja stvara platformu za efikasnu zaštitu zaposlenih na radu. Ovaj rad bavi se analizom zakonske regulative o bezbednosti $i$ zdravlju na radu u Republici Srbiji i Republici Crnoj Gori. Komparacijom ova dva pravna sistema u oblasti bezbednosti i zdravlja na radu biće omogućeno sagledavanje prednosti i nedostataka svakog od njih, uz određene ideje za njihovo unapređenje.

Ključne reči: bezbednost i zdravlje na radu, propisi, Republika Srbija, Republika Crna Gora.

Proofreading and copy-editing:

Gordana Ignjatović 